\title{
FACTORS THAT AFFECT EMPLOYMENT OUTCOMES AMONG TRANSITION-AGE ADOLESCENTS WITH VISION IMPAIRMENT: A SYSTEMATIC LITERATURE REVIEW
}

\author{
Tommy H. Firmanda
}

Flinders University, Adelaide, SA

\begin{abstract}
This study aims to identify and synthesise the study of employment outcomes in the transition to adulthood for young people with visual impairment. Methods: The PRISMA Statement Protocol is used as a guide in conducting a systematic review of the literature, including the criteria for choosing a study, a search strategy, and a synthesis of findings. Results: Seven studies of factors influencing posthigh school employment outcomes among adolescent transition-age with visual impairment were identified. Six studies used data from National Longitudinal Transition Study 2 (NLTS2), and one study using RSA Case Service Report (RSA-911). Of the seven studies with quantitative design, only one study is a correlational study. All studies reported a significant relationship and influence between work-related factors and post-secondary education employment outcomes. 13 factors affect positively and only 1 factor that has a negative influence. Discussion: Among the 13 factors, eight factors confirm the results of previous studies. While the other five factors still need to be investigated further, although in this study the five factors have a great potential as a predictor of successful work of youth with visual impairment. Limitations of data sources need to be a concern in conducting future studies. Implications for practitioners: The high unemployment rate in this population indicates a lack of evidence-based research in this area. Educational practitioners encouraged to evaluate intervention programs to improve the success of the transition-age youths with vision impairment and publish the findings for later can be use as a basis for developing appropriate livelihood policies and education programs.
\end{abstract}

Keywords: Employment, Transition, Post-Secondary School, Blind, Visual Impairment, Factor, Outcomes, Youth

\section{Introduction}

Youths who are blind and has low vision, and involving in programs provide by vocational rehabilitation agencies was predicted to have a successful employment, influencing by few factors including selfdetermination, work experience, academic competence, use of adaptive technology, and locus of control (McDonnall \& Crudden, 2009).

Employment participation among individuals with visual impairment influencing by some factors such as

\footnotetext{
* Corresponding author: Tommy H. Firmanda Email: firmanda.th@gmail.com

Published online at http://IJDS.ub.ac.id/2018- 1

Copyright $@ 2018$ PSLD UB Publishing. All Rights Reserved
}

communication training and education (Goertz, van Lierop, Houkes, \& Nijhuis, 2010). Low rates of employment among individuals with visual impairment remains

stable, even though schools has prepared them through programs that embedded in the curriculum. This situation emerges due to the barriers toward access to employment. The barriers include attitudes of employers and the general public; transportation problems; and lack of access to print, adaptive equipment, and accommodations (McDonnall \& Crudden, 2009).

Studies on interventions to increase career awareness and job search skills, including 
social skills, engagement in career development activities, family involvement, and work experience have been conducted (Cavenaugh \& Giesen, 2012). The majority of research have now been developed to determining factors and predictors that were influencing young people, particularly those who has a visual impairment.

Employment is an activity which is become the most preferred option for the majority of adolescents with disabilities, in particular, those with visual impairment. In fact, McDonnall, Zhou, and Crudden (2013) mentioned in their paper that the number of persons with visual impairment who were in the labor force is only about one million (Bureau of Labor Statistics, 2012), compared with 142 million people without disabilities were employed Bureau of Labor Statistics, 2013). Although the results of this report are done in the United States, in general, the ratio of the number of workers with visual impairment and labor without disabilities is similar to other countries. These very striking differences occur due to various factors, both internal factors such as the skills of the person, access to employment information, the disability itself (O'Day, 1999) as well as external factors such as knowledge and attitudes of employers towards the blind (McDonnall, Crudden, \& O'Mally, 2015; McDonnall, O'Mally, \& Crudden, 2014; McDonnall et al., 2013). Moreover, O'Day (1999) have categorized the barriers into three categories namely personal (internal), societal (interaction with the community) and programming barriers.

Meanwhile, experts in the field of visual impairment have been suggested to use a special instruction through the Expanded Core Curriculum (ECC) to improve the quality of the graduates (Huebner, Brand-Adam, Stryker, \& Wolffe, 2004). ECC consists of nine fields of skills which are compulsory for students with visual impairment beyond the core academic skills. Fields of these skills are skills compensation, orientation and mobility (O \& M), social interaction, independent living, recreation and leisure, assistive technology, efficiency sensory, selfdetermination and career education (Hatlen, 1996; Sapp \& Hatlen, 2010). To improve the employment outcomes, ECC has provided the Career Education to ensure that these young people have access to their preferred job.

Some studies do exist in examining the ways to improving the implementation of the Expanded Core Curriculum (ECC). A study by Pogrund, Darst, and Boland (2013) found that short-term programs are efficient and more than satisfactory in meeting students' needs associated with the areas of ECC. Other research shows the critical of social skills (Botsford, 2014) and assistive technology (Ferronato \& Ukovic, 2014; Zhou, Smith, Parker, \& Griffin-Shirley, 2013) in accessing employment for people who are blind and visually impaired. Although lots of studies related to intervention to improve the employability of these students had been established, not one of those studies that directly resulted in employment outcomes (Cavenaugh \& Giesen, 2012).

Indeed, students with blindness and visual impairment have gained access to education with special instruction, especially in the areas of employment. Although these students have received special instruction through the ECC, the number of students who gain success in employment is considerably lower than their peers without disabilities. The semantic literature review is used to address the issue of employment among this young adult. Furthermore, the systematic literature review was used in this study because this method has the same rigor as primary research and has been considered as one of the empirical (Cavenaugh \& Giesen, 2012) research methods. In the process, this research should go through several protocols including source search (database), determine keywords and limits, screening process, collect data to be extracted from the relevant articles, and make a summary of data to be reported (Moher, Liberati, Tetzlaff, Altman, \& Group, 2009).

The low-incidents in this population affects the limited amount of research available in this field. ECC is one of the ways used to help visually impaired youth prepare to make the transition to post-secondary school activities such as higher education and employment. Nevertheless, this curriculum still needs to be developed to ensure students' readiness and successful after graduating from 
high school. The aim of the study presented here is to identify factors influencing preparatory employment outcomes post-high school to assist educator experts to provide an empirical basis for curriculum development as well as providing preparation programs and instructions. Furthermore, this study also aims to confirm previous findings so that depth understanding can be built related to this area. The following research question is used to conduct the study: What factors are influencing the employment outcomes of transition-aged adolescents who are visually impaired?

\section{Methods}

\subsection{Data Sources}

In conducting the SLR study, the author used PRISMA Statement, the preferred reporting items for systematic reviews and meta-analyses (Moher et al., 2009) to improve the quality under review of the study and to structure the review. The author conducts electronic searches using the search engine from Find@Flinders to identify all publications between 2011 and 2017; the studies was collected using NLTS2 data sets (Waves 1-5) and data from other relevant studies to determine the transitional success factor or predictor of post-high school outcome associated with employment among adolescents with vision impairment. The database used for search includes ProQuest Central, Educational Resources Information Center (ERIC) U.S. Department of Education, SAGE Journals, SpringeLink, and Sage Publications. Keywords of the following search terms is used: "post-high school", "transition", "employment", "outcome", "blindness", "visual impairment", "National Longitudinal Transition Study 2", and "NLTS2". Other relevant articles related to the problems in this study were also obtained from Google Scholar search engine and ProQuest Dissertation \& Thesis Global database as additional resources with the same keywords. Because the researchers in this field is limited, the author expands the literature search through the additional database, ProQuest Social Sciences Premium Collection with expanding the publication time limitation between 2005 to 2017 . Finally, the author searches the article referral list identified through an electronic search that meets the inclusion criteria to identify additional articles related to this review. As a result of an initial search, the author has identify three articles using NLTS2 data.

\subsection{Inclusion Criteria}

The inclusion criteria for this systematic review include (a) predictor variables related to a transition program from the expanded core curriculum areas and (b) variables related to a post-school employment for the young adult with vision impairment. After obtaining the relevant articles, the author also searched the reference list to identify additional interesting studies. Also, the authors do not include unpublished articles in peer-reviewed journals (but consider Dissertation as an alternative to enriching the review results), and not using participant outside of transitionaged youth who are both still attending school and have finished high school, and their parents.

\subsection{Data Extraction and Synthesis}

First, all articles that occurred as a result of putting the keywords in the search engine has shown 178 studies combined from 9 databases. Twenty-four articles were selected by title and abstract. At this stage, each item is extracted to identify information related to the year of publication, the type of data used, the age of the participant, the number of participants, the focus of the targeted study, the research results, and the research design. The author groups research into two categories: in-school and post-school.

\section{Result}

From the relevant studies found through the above procedure, a total of 7 studies were reviewed, eight excluded from further analysis. Based on these selected studies, 
4,932 participants aged between 13 and 24 who has a vision impairment were recruited for this study.

\section{Factors Influencing Outcomes for Transition-Age Youth with Visual Impairment \\ NLTS2 Data}

Connors, Curtis, Emerson, and Dormitorio (2014) found that some factors did influencing students with vision impaired' success after high school. In this study, successful outcomes were defined based on whether the individual had a job or entering further study/higher education during the twoyear wave, or both (Connors et al., 2014). Using NLTS2 data and by utilizing a generalized estimating equation GEEs model using SAS 9.2 software, six independent factors was analyzed instead of 11 factors from the original model. There was $78 \%$ successful and $22 \%$ unsuccessful young people with visual impairment from the total $(n=460)$.

The study identified variables affected the success and unsuccess outcomes of this population. Based on the GEE model, it was found that income, vision, secondary disability, high school completion status, working for high school salaries, and individual years leaving high school, are among the factors affecting post-school success amongst youth with visual impairments (Connors et al., 2014). In fact, the results show that people with paid working experience during high school, high school or diploma, have graduated (more than four years) tend to be 2 to 3 times more likely to succeed. Also, demographic or physical characteristics are also found to be associated with successful blind youth in achieving success. It should be noted that although the results of this study are promising, the study lacks sufficient data due to a large amount of lost data, limited post-secondary schools available, and that the fact that the data obtained is from self-report. Nevertheless, the role of the secondary level completion factors and initial work experience is aligned with the literature.
A study by Zhou et al. (2013) was also using data from NLTS2 Wave 3 (20032005) and the data was analyzed using the Complex Samples module of SPSS 17.0 to compare between two groups of participants. The results of the study show that for inschool adolescents with vision impairment group, gender variables and the severity of vision loss do not significantly affect employment outcomes. While the multidisability variables or double disability status have a negative impact on job performance $(\mathrm{t}$ $=3.24, \mathrm{p}=.002$ ) and only adolescent perception variable to computer competence and self-perceived computer ability that have a positive relationship with paid work and job performance $(\mathrm{T}=3.00, \mathrm{p}=0.004)$.

Meanwhile, the results of data analysis on out-of-school adolescents with visual impairment also showed similar trends. The data indicate that only the computer's perceived competence and the perception of high computer ability have a positive relationship with job performance and have paid work $(\mathrm{t}=2.10, \mathrm{p}=.040)$. This result indicates that both the youth in the school and Out of school, computer competence owned by them is one of the factors affecting employment. In this study, some of the limitations identified was the less reliable and valid data because the data could not describe the current situation, and the measurement results were less able to describe the real skills of the participants, the less accurate research design (not using experimental design), and the study was using categorical variables that are too broad.

In the study, McDonnall (2011) has utilized the logistic regression as the statistical technique to analyze the data and using SAS version 9.2 as the statistical software. Twentytwo potential predictor variables were analyzed and only 13 predictors $(\mathrm{p}<.05)$ and two predictors $(\mathrm{p}<.10)$ show a significant relationship with employment from the previous research were analyzed using logistic regression models. After made more selective variables, two categories (20-hour work model and 35-hour work model) has included receipt of SSI, the level of vision loss, parental prediction and independent travel skills as the possible factors. That using the 
largest sample available in the NLTS2 data set. The current study release that only four variables proofed to be a significant factor includes early work experiences, the number of recent work experiences, difficulty with transportation, and completion of a postsecondary program (McDonnall, 2011). Others two variables from previous studies also emerged as consistent predictors in this study include the peer social skills and independent travel skills (McDonnall, 2010, 2011; McDonnall \& Crudden, 2009). Similar to other researchers using the NLTS2 data set, McDonnall (2011) also asserts that small sample and a large amount of missing data on some independent variables occurred as limitations in this study. Further, he suggests that other variables such as personal autonomy and mathematics achievement might also have a strong effect on predicted successful employment for people with visual impairment.

The study was conducted to determine the predictor of employment associated with the Orientation and Mobility (O\&M) skills. Many data analysis were used and to predict the probability of employment, the author preferred to utilized two binomial multiple logistic regressions based on some variables such as campus travel skills, community travel abilities, and outcome expectations, holding age and level of vision constant (Cmar, 2015). Using the NLTS2 from Wave 4 and Wave 5, the results has confirmed that young people who have a visual impairment condition with high ratings on community and high outcome expectations were significantly have a paid job. Despite its unexpected result which shows that both variables were not significantly predicted post-high school outcomes based on the result of both regression model, these study findings still consistent with previous findings which found that independent travel skills as one factor that predict successful employment among adolescents with vision impairments (McDonnall, 2011; Wolffe \& Kelly, 2011; cited in Cmar, 2015). It needs to be noted as limitations that in this study the authors do not consider the fluctuation of the skill of $\mathrm{O} \& \mathrm{M}$, the possibility of involvement of other

Cite this as:

Firmanda, Tommy J. Factors That Affect Employment Outcomes Among Transition-Age Adolescents With Vision Impairment: A Systematic Literature Review. Indonesian Journal of Disability Studies (IJDS).2018: Vol. 5(1): PP 132 - 144. variables, as well as issues related to the skills methodology of $\mathrm{O} \% \mathrm{M}$.

The data of the study conducted by Kelly (2011) were analyzed using three different methods including a descriptive analysis, multilevel modeling and generated descriptive statistics for each assessment. The study also uses data from the NLTS2 data set. It was revealed some findings related to the use of assistive technology among youth with visual impairment. One of the findings shows that those students are likely to have a paid job if only they have using assistive technology during the secondary school period (Kelly, 2011).

In this study, McDonnall and O'Mally (2012) was using the NTLS2 data set (Wave 2 to 4) and utilised different techniques to analysis the data for 4 different research focus, including use the logistic regression, and SAS version 9.2 (for question 1 dan 2), an independent $t$ test for question 3 (Cohen' $s$ d), and using a chi-square, with two separate analyses run by wave (Cramer' s V) as the statistical method. The study indicates that the variable of the characteristics of early work experiences, including finding a job independently, holding multiple jobs, and holding jobs for longer periods of time do have a positive impact on adolescents with vision impairment's future employment outcomes. McDonnall and O'Mally (2012) also suggests that the teachers or services providers should consider some other characteristics such as the types of work, how the jobs were obtained, or how long the jobs lasted, instead of just rely on the experience of being employed during high school. The characteristics of the initial identified work experience established in this study are the experience of finding employment independently and the length of previous work including the number of paid jobs in the last two years. Alternatively, other characteristics also need to be taken into consideration such as multiple holding experiences that can help youth with visual impairments to gain specific job skills, improve their interview skills and find their work, enhance their professional contact network, and build a working history that may look attractive For the Employer. The limitations of this study are the missing 
data and the limited to the variables (the characteristics) and the amount of participant that were available to be analyzed.

\subsection{RSA Case Service Report}

Additional study is added to make a better picture of the factors that affecting employment outcomes among youth who is visually impaired. The study has used the data from the annual RSA Case Service Report (RSA-911) and was analyzed using Multiple logistic regression (using SPSS version 18) as the statistical technique. The results identified four categories of factors that affecting competitive employment include demographic and educational factors, disability factors, work and support factors, and service factors (Giesen \& Cavenaugh, 2012). The scope of the data source is limited to the RSA-911 data, and this situation was emerge as a limitation that appearing in this study. The summary of the findings can be seen in Table 2 below.

\subsection{Discussion}

The review of post-high school outcomes related to employment for youths with visual impairment conducted over the past decade has revealed some significant findings. The purpose of this review is to identify factors and predictors that may affect or have an association with the employment outcomes of adolescents with visual impairment. Also, this review may only confirm existing findings or may also add to some other factors or predictors obtained through literature searches from 2011 to 2017.

Seven studies related to employment outcomes among transitional-age youth who are visually impaired identified. The results of the synthesis revealed that the factors and/or predictors found in this review were significantly related and positively affected youths' employability, including early work experience during high school, high school completion which related to academic competence, time of leaving high school, level of vision severity, presence of an additional or multiple disability, perceptions of computer competence, the quantity of current jobs, community travel (O\&M) skills, the persons' network and social skills, completion of postsecondary programs, outcome expectations, the use of assistive technology, experience finding a job independently, the length of the previous job, as well as the services of the placement, college attendance, and general or vocational services. Meanwhile, in this study only found one factor that negatively affects employment outcomes is the receipt of SSI.

Perhaps the concern of this review is the lack of recent research published over the last seven years that meets the selection criteria set by the author. Of the 15 potential empirical studies found through the PRISMA procedure, only about $40 \%$ (6) of the studies used data from NLTS2, and only one mineral study using RSA-911 data. Furthermore, only in 4 of the seven studies reported more than two factors and predictors findings affecting employment among youth with vision impaired (Connors et al., 2014; Giesen \& Cavenaugh, 2012; McDonnall, 2011; McDonnall \& O'Mally, 2012). Several studies reported similar results, including the influence of early work experience factors (Connors et al., 2014; Giesen \& Cavenaugh, 2012; McDonnall \& O'Mally, 2012), educational factor (Connors et al., 2014; Giesen \& Cavenaugh, 2012), the severity of visual impairment and the presence of additional disabilities (Connors et al., 2014; Giesen \& Cavenaugh, 2012), independent travel skills (Cmar, 2015; McDonnall, 2011), as well as the negative influence of the receipt of SSI (Giesen \& Cavenaugh, 2012; McDonnall \& O'Mally, 2012). Several factors that emerged in this study have confirmed the results of previous studies. There are only a few factors that can be considered as a new and potential factor or predictors for predicting employment outcomes in this population. These factors include time of leaving high school, perceptions of computer competence, completion of post-secondary programs, the experience of independent job seeking, and the length of the previous job. One interesting point from the results of this study is the lack of research related to the use of assistive technology and its relation to improving employability and competitiveness for students with visual impairment. Also, yet in this study, ethical issues and other obstacles 
may hinder the application of randomized studies in publicly funded education and rehabilitation environments.

\subsection{Limitations}

Even though this review has identified several promising factors, the implications on field practice must still be considered by the conditions and situations of the population sample. The majority of the research used in this study uses data from NLTS2, where this dataset has limitations regarding validity and reliability. The amount of missing data and a small number of sample is one of the issues need to be a concern. Also, data from NLTS2 and RSA represent young populations with vision impairment domiciled in the United States. Consequently, the findings of this study may not be broadly generalizable to the same group with the different background, including demographic and cultural background, such as in developing countries. Unfortunately, not many studies are conducted in such countries as the United States does. However, the results of this study can be used as a reference and consideration for further study in the future and can be utilized for the development of both educational programs and policies.

\section{Conclusion}

Although this literature review is based on several studies that use weak data due to the limited data and research resources available in this area, the author's findings can illustrate the conditions of the adolescent with visual impairment, and provide the basis for public policy makers, service providers and curriculum developers. The authors have identified factors related to transition-age youth post-secondary employment outcomes so that service vendors in the education area can consider these factors as a basis for developing appropriate programs and can increase success in the employment for this population in the future. The implicatin of this study is to encourage educational practitioners to evaluate intervention programs to improve the success of the transition-age youths with vision impairment and publish the findings for later can be use as a basis for developing appropriate livelihood policies and education programs for policies maker.

\section{References}

Botsford, K. D. (2014). Quality of life as a transition outcome for youth with visual impairments: Testing competing models using National Longitudinal Transition Study-2 (NLTS2) data: University of Northern Colorado.

Cavenaugh, B., \& Giesen, J. M. (2012). A systematic review of transition interventions affecting the employability of youths with visual impairments. Journal of Visual Impairment \& Blindness, 106(7), 400.

Cmar, J. L. (2015). Orientation and Mobility Skills, Outcome Expectations, and Employment for Youth with Visual Impairments: Findings from the National Longitudinal Transition Study-2.

Connors, E., Curtis, A., Emerson, R. W., \& Dormitorio, B. (2014). Longitudinal analysis of factors associated with successful outcomes for transition-age youths with visual impairments. Journal of Visual Impairment \& Blindness (Online), 108(2), 95.

Ferronato, L., \& Ukovic, A. (2014). Enabling positive work outcomes for people with low vision: Two case studies. Work, 47(3), 381386.

Giesen, J. M., \& Cavenaugh, B. S. (2012). Transition-age youths with visual impairments in vocational rehabilitation: A new look at competitive outcomes and services. Journal of Visual Impairment \& Blindness, 106(8), 475.

Goertz, Y. H., van Lierop, B. A., Houkes, I., \& Nijhuis, F. J. (2010). Factors related to the employment of visually impaired persons: A systematic literature review. Journal of Visual Impairment \& Blindness, 104(7), 404.

Kelly, S. M. (2011). The use of assistive technology by high school students with visual impairments: A second look at the 
current problem. Journal of Visual Impairment \& Blindness, 105(4), 235.

McDonnall, M. C. (2010). Factors predicting post-high school employment for young adults with visual impairments. Rehabilitation Counseling Bulletin, 54(1), 36-45.

McDonnall, M. C. (2011). Predictors of employment for youths with visual impairments: Findings from the second National Longitudinal Transition Study. Journal of Visual Impairment \& Blindness, 105(8), 453.

McDonnall, M. C., \& Crudden, A. (2009). Factors affecting the successful employment of transition-age youths with visual impairments. Journal of Visual Impairment \& Blindness, 103(6), 329.

McDonnall, M. C., Crudden, A., \& O'Mally, J. (2015). Predictors of employer attitudes toward people who are blind or visually impaired as employees. Journal of Vocational Rehabilitation, 42(1), 41-50.

McDonnall, M. C., \& O'Mally, J. (2012). Characteristics of early work experiences and their association with future employment. Journal of Visual Impairment \& Blindness, 106(3), 133.

McDonnall, M. C., O'Mally, J., \& Crudden, A. (2014). Employer knowledge of and attitudes toward employees who are blind or visually impaired. Journal of Visual Impairment \& Blindness (Online), 108(3), 213.

McDonnall, M. C., Zhou, L., \& Crudden, A. (2013). Employer attitudes towards persons who are blind or visually impaired: Perspectives and recommendations from vocational rehabilitation personnel. Journal of Rehabilitation, 79(3), 17.

Moher, D., Liberati, A., Tetzlaff, J., Altman, D. G., \& Group, P. (2009). Preferred reporting items for systematic reviews and meta- analyses: the PRISMA statement. PLoS med, 6(7), e1000097.

O'Day, B. (1999). Employment Barriers for People with Visual Impairments. Journal of Visual Impairment \& Blindness, 93(10).

Pogrund, R. L., Darst, S., \& Boland, T. (2013). Evaluation study of short-term programs at a residential school for students who are blind and visually impaired. Journal of Visual Impairment \& Blindness (Online), 107(1), 30.

Zhou, L., Smith, D. W., Parker, A. T., \& Griffin-Shirley, N. (2013). The relationship between perceived computer competence and the employment outcomes of transition-aged youths with visual impairments. Journal of Visual Impairment \& Blindness (Online), 107(1), 43. 
Table 1: Characteristics of included studies

\begin{tabular}{|c|c|c|c|c|c|}
\hline Study Authors & Participants & $\begin{array}{c}\text { Interest } \\
\text { (Study Focus) }\end{array}$ & $\begin{array}{l}\text { Context } \\
\text { Setting }\end{array}$ & Outcomes & Study Type \\
\hline $\begin{array}{l}\text { Connors, Elyse; } \\
\text { Curtis, Amy; } \\
\text { Dormitorio, } \\
\text { Benedict (2014) }\end{array}$ & $\begin{array}{l}460 \text { students, aged } \\
13 \text { to } 16.56 \% \text { were } \\
\text { males, }(61 \%) \text { low } \\
\text { vision, } 33 \% \text { blind } \\
\text { and } 6 \% \text { deafblind. } \\
\text { white }(67 \%), 18 \% \\
\text { African American, } \\
12 \% \text { Hispanic, and } \\
3 \% \text { "other." }\end{array}$ & $\begin{array}{l}\text { Factors, successful } \\
\text { employment } \\
\text { outcomes }\end{array}$ & United States & $\begin{array}{l}\text { Specific year exiting } \\
\text { high school, paid } \\
\text { work experience } \\
\text { during high school, } \\
\text { and high school } \\
\text { completion related to } \\
\text { employment success }\end{array}$ & $\begin{array}{l}\text { Quantitative study } \\
\text { using data from } \\
\text { five waves of the } \\
\text { 10-year National } \\
\text { Longitudinal } \\
\text { Transition Study-2 } \\
(2002-2008)\end{array}$ \\
\hline $\begin{array}{l}\text { Zhou, Li ; Smith, } \\
\text { Derrick ; Parker, } \\
\text { Amy ; Griffin- } \\
\text { Shirley, Nora } \\
\text { (2013) }\end{array}$ & $\begin{array}{l}200 \text { in-school } \\
\text { youths }(n=3,407), \\
190 \text { out-of-school } \\
\text { youths }(n=4,951)\end{array}$ & $\begin{array}{l}\text { self-perceived } \\
\text { computer competence } \\
\text { and having paid jobs, } \\
\text { employment }\end{array}$ & United States & $\begin{array}{l}\text { In school and out } \\
\text { school with high self- } \\
\text { perceived computer } \\
\text { competence and have } \\
\text { vision loss only, get } \\
\text { more paid job }\end{array}$ & $\begin{array}{l}\text { Quantitative using } \\
\text { the database of } \\
\text { NLTS2. }\end{array}$ \\
\hline $\begin{array}{l}\text { Mcdonnall, } \\
\text { Michele (2011) }\end{array}$ & 250 youth (16-24) & $\begin{array}{l}\text { Predictors for } \\
\text { employment }\end{array}$ & United States & $\begin{array}{l}\text { early work } \\
\text { experiences, the } \\
\text { number of recent } \\
\text { work experiences, } \\
\text { difficulty with } \\
\text { transportation, and } \\
\text { completion of a } \\
\text { postsecondary } \\
\text { program as the factors }\end{array}$ & $\begin{array}{l}\text { Quantitative using } \\
\text { the database of } \\
\text { NLTS2. }\end{array}$ \\
\hline $\begin{array}{l}\text { Cmar, Jennifer } \\
\text { Lynn (2015) }\end{array}$ & $\begin{array}{l}510 \text { students }(68 \% \\
\text { is low vision, } 34 \% \\
\text { had secondary } \\
\text { disability), aged } \\
14-18\end{array}$ & $\begin{array}{l}\text { O\&M skills, outcome } \\
\text { expectations, and } \\
\text { predictor of } \\
\text { employment }\end{array}$ & United States & $\begin{array}{l}\text { high community } \\
\text { travel scores, high } \\
\text { outcome expectations }\end{array}$ & $\begin{array}{l}\text { Quantitative using } \\
\text { the database of } \\
\text { NLTS2 }\end{array}$ \\
\hline $\begin{array}{l}\text { Kelly, Stacy M } \\
(2011)\end{array}$ & $\begin{array}{l}\text { Wave } 1, \mathrm{n}=80 \\
\text { Wave } 2, \mathrm{n}=40\end{array}$ & $\begin{array}{l}\text { Handicapped } \\
\text { assistance sevices, }\end{array}$ & United States & $\begin{array}{l}\text { Students with VI who } \\
\text { get paid job } 1,5 \text { times }\end{array}$ & $\begin{array}{l}\text { Qualitative using } \\
\text { telephone }\end{array}$ \\
\hline
\end{tabular}


IJDS 2018; Vol. 5 No. 1, May 2018, pp. 132-144

ISSN: $2355-2158$

\begin{tabular}{|c|c|c|c|c|c|}
\hline & $\begin{array}{l}\text { and Wave } 3, n=90 \\
\text { youths aged } 13-18\end{array}$ & employment & & more likely to use AT & $\begin{array}{l}\text { interview, } \\
\text { Quantitative using } \\
\text { survey from } \\
\text { NLTS2 }\end{array}$ \\
\hline $\begin{array}{l}\text { McDonnall, } \\
\text { Michele Capella; } \\
\text { O'Mally, Jamie. } \\
\text { (2012) }\end{array}$ & $\begin{array}{l}\text { Q1 (310), Q2 } \\
(110), \text { Q3 (110), } \\
\text { Q4 (120 and 180), } \\
\text { youths above 17/18 }\end{array}$ & $\begin{array}{l}\text { Characteristics, early } \\
\text { work experiences, } \\
\text { employment }\end{array}$ & United States & $\begin{array}{l}\text { Characteristics: the } \\
\text { types of work, how } \\
\text { the jobs were } \\
\text { obtained, or how long } \\
\text { the jobs lasted }\end{array}$ & $\begin{array}{l}\text { Quantitative using } \\
\text { the database of } \\
\text { NLTS2 }\end{array}$ \\
\hline $\begin{array}{l}\text { Giesen, J Martin; } \\
\text { Cavenaugh, } \\
\text { Brenda S (2012) }\end{array}$ & $\begin{array}{l}\mathrm{N}=2,282 \\
\text { Aged under } 21 \\
46.8 \% \text { female }\end{array}$ & $\begin{array}{l}\text { factors that affect the } \\
\text { employment } \\
\text { outcomes, vocational } \\
\text { rehabilitation } \\
\text { program }\end{array}$ & United States & $\begin{array}{l}\text { influences, "risk } \\
\text { factors,", predictors } \\
\text { of competitive } \\
\text { employment }\end{array}$ & $\begin{array}{l}\text { Quantitative using } \\
\text { RSa-911 data set }\end{array}$ \\
\hline
\end{tabular}


Table 2: Details of Study findings

\begin{tabular}{|c|c|c|c|c|c|c|}
\hline Source & $\begin{array}{c}\text { Finding / } \\
\text { Concept \#1 }\end{array}$ & $\begin{array}{c}\text { Finding / } \\
\text { Concept \#2 } \\
\end{array}$ & $\begin{array}{c}\text { Finding / } \\
\text { Concept \#3 }\end{array}$ & $\begin{array}{c}\text { Finding / } \\
\text { Concept \#4 } \\
\end{array}$ & $\begin{array}{c}\text { Finding / } \\
\text { Concept \#5 }\end{array}$ & $\begin{array}{c}\text { Finding / } \\
\text { Concept \#6 }\end{array}$ \\
\hline $\begin{array}{l}\text { Connors, } \\
\text { Elyse; Curtis, } \\
\text { Amy; } \\
\text { Dormitorio, } \\
\text { Benedict } \\
(2014)\end{array}$ & $\begin{array}{l}\text { Individuals who worked } \\
\text { for pay in high school } \\
\text { were } 3.6 \text { times more likely } \\
\text { to be successful following } \\
\text { high school than } \\
\text { individuals who did not } \\
\text { work in high school }\end{array}$ & $\begin{array}{l}\text { Individuals who } \\
\text { completed high } \\
\text { school had } 3.3 \\
\text { times the odds of } \\
\text { being successful } \\
\text { over those who } \\
\text { did not complete } \\
\text { high school. }\end{array}$ & $\begin{array}{l}\text { individuals } \\
\text { who left high } \\
\text { school in } \\
2000-2002 \\
\text { were } 2.2 \\
\text { times more } \\
\text { likely to be } \\
\text { successful } \\
\text { compared to } \\
\text { those who left } \\
\text { high school in } \\
\text { 2006-2008 }\end{array}$ & $\begin{array}{l}\text { income, vision, and } \\
\text { presence of an } \\
\text { additional disability } \\
\text { were also found to be } \\
\text { associated with success } \\
\text { longitudinally up to } \\
\text { eight years post-high } \\
\text { school }\end{array}$ & & \\
\hline $\begin{array}{l}\text { Zhou, Li ; } \\
\text { Smith, Derrick } \\
\text {; Parker, Amy ; } \\
\text { Griffin-Shirley, } \\
\text { Nora (2013) }\end{array}$ & $\begin{array}{l}\text { For both the in-school and } \\
\text { out-of-school youths, } \\
\text { those with high } \\
\text { perceptions of their own } \\
\text { computer competence } \\
\text { were more likely to be } \\
\text { employed than were those } \\
\text { who thought they had low } \\
\text { computer competence }\end{array}$ & $\begin{array}{l}\text { when gender, the } \\
\text { severity of vision } \\
\text { loss, and multiple } \\
\text { disability status } \\
\text { were held constant }\end{array}$ & & & & \\
\hline $\begin{array}{l}\text { Mcdonnall, } \\
\text { Michele (2011) }\end{array}$ & $\begin{array}{l}\text { Youths who had just two } \\
\text { jobs in the past two years } \\
\text { had odds } 1.6 \text { to } 2.1 \text { times } \\
\text { higher of being employed } \\
\text { at Wave } 4 \text { than did youths } \\
\text { who held no jobs in the } \\
\text { past two years. }\end{array}$ & $\begin{array}{l}\text { Youths who } \\
\text { reported that } \\
\text { transportation was } \\
\text { easy or somewhat } \\
\text { easy had odds } 2.4 \\
\text { times greater of } \\
\text { being employed } \\
\text { than did those who } \\
\text { reported } \\
\text { difficulties with } \\
\text { transportation }\end{array}$ & $\begin{array}{l}\text { the more } \\
\text { diverse and } \\
\text { expansive a } \\
\text { person's } \\
\text { network is, } \\
\text { the more } \\
\text { likely that this } \\
\text { network will } \\
\text { result in a } \\
\text { successful job } \\
\text { lead }\end{array}$ & $\begin{array}{l}\text { Youths who had } \\
\text { completed a } \\
\text { postsecondary program } \\
\text { had odds three times } \\
\text { greater of being } \\
\text { employed at } 35 \text { hours } \\
\text { per week or more }\end{array}$ & $\begin{array}{l}\text { Youths whose parents } \\
\text { indicated that they } \\
\text { could get to places } \\
\text { outside the home on } \\
\text { their own pretty well } \\
\text { or very well were } \\
\text { almost three times as } \\
\text { likely to be employed } \\
\text { full time }\end{array}$ & $\begin{array}{l}\text { Youths who were invited } \\
\text { by friends to social } \\
\text { activities had } 3.5 \text { times } \\
\text { greater odds of being } \\
\text { employed than did those } \\
\text { who were not }\end{array}$ \\
\hline
\end{tabular}




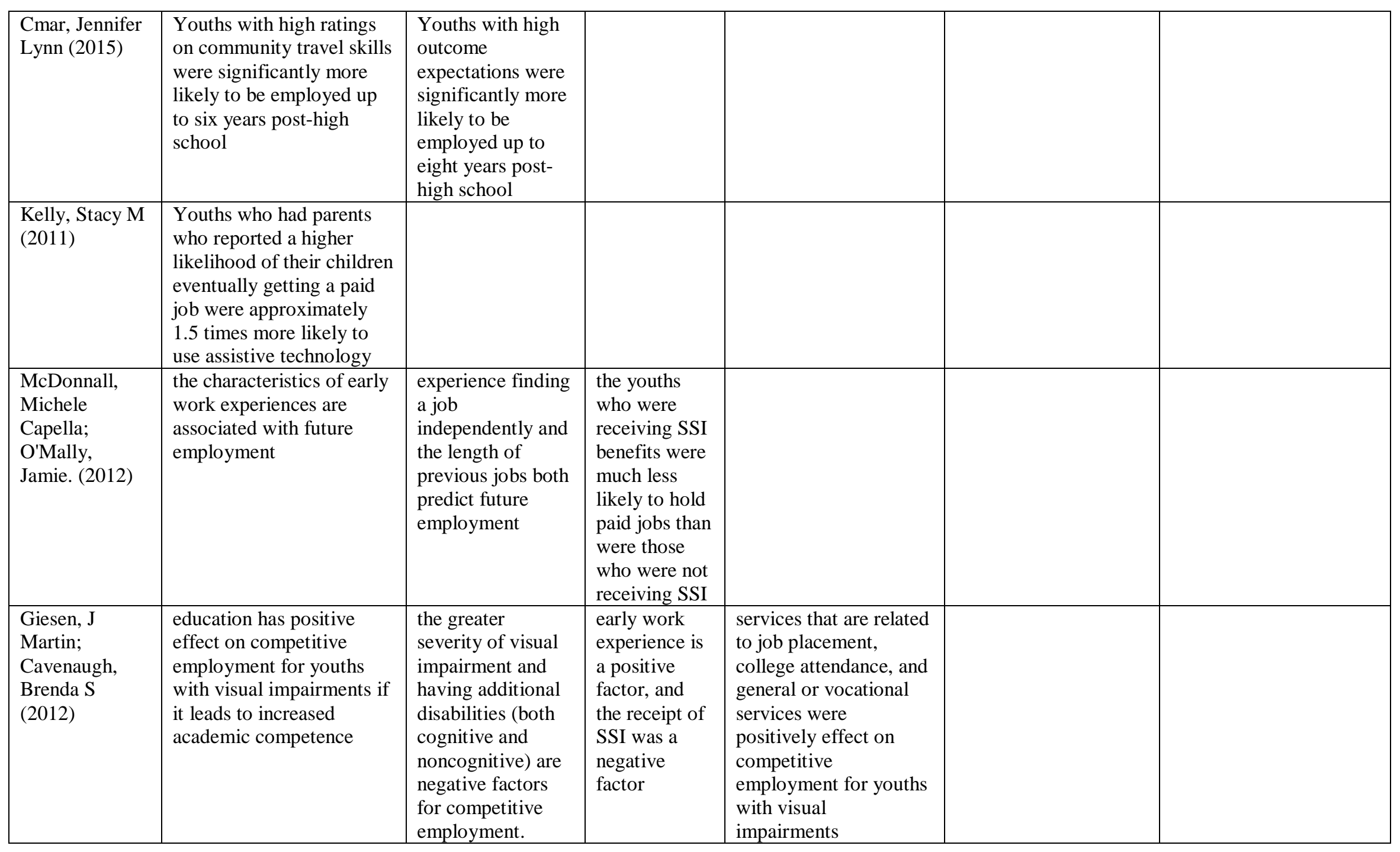

Firmanda, Tommy J. Factors That Affect Employment Outcomes Among Transition-Age Adolescents With Vision Impairment: A Systematic Literature Review. Indonesian Journal of Disability Studies (IJDS).2018: Vol. 5(1): PP 132 - 144. 
27 of records identified through

searching databases: ProQuest (13),

ERIC (1), SAGE Journals (15), Sage

Publication (O), SpringeLink $(O)$

Using the keywords: post-high school,

transition, employment, outcome,

blindness, visual impairment, National

Longitudinal Transition Study 2, NLTS2

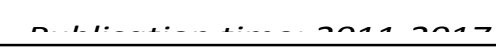

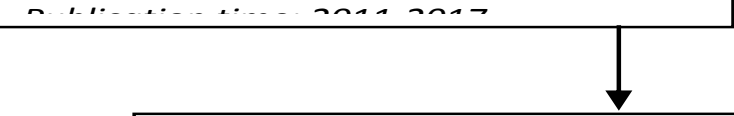

148 of additional records identified

through other sources (e.g. personal

communication) ProQuest Dissertation

\& Thesis Global (124), Flinders Library,

Google Scholar, and ProQuest Social

Sciences Premium Collection (24)

178 of records after duplicates removed and combibined
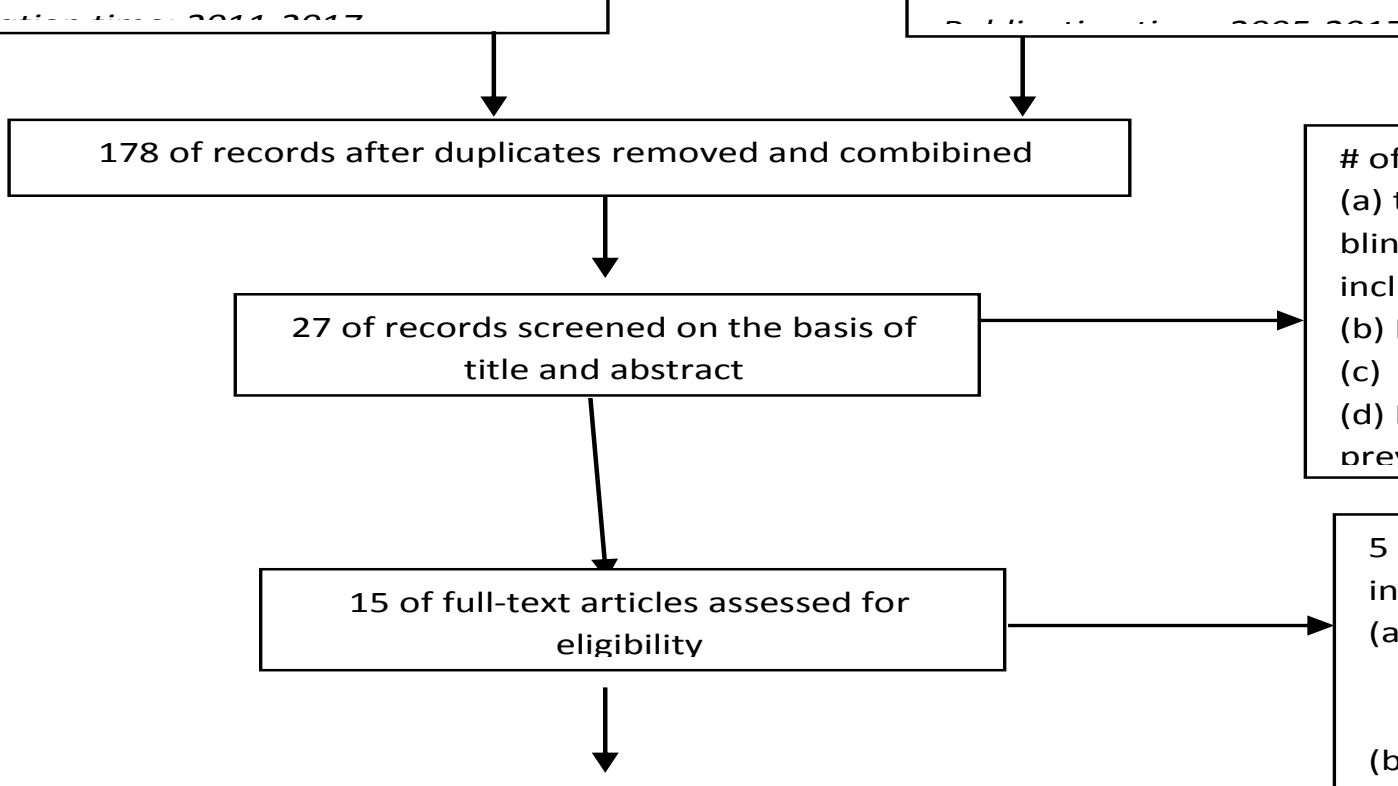

7 of studies synthesized

\# of records excluded. Reasons included

(a) the participants is identified as non-

blindness and visial impairment or not

included these students as participant

(b) Not related to employment for $\mathrm{VI}$

(c) not in therange of publication year

(d) Not peer reviewed (including

orevious literature reviews)

5 of full-texts excluded. Reasons

included ..........

(a) Participant is not a transition-aged youth both attending school and finished high school

(b) Not discussing factors associated with employment

Figure 1. FLOW Chart Diagram

Firmanda, Tommy J. Factors That Affect Employment Outcomes Among Transition-Age Adolescents With Vision Impairment: A Systematic Literature Review.

Indonesian Journal of Disability Studies (IJDS).2018: Vol. 5(1): PP 132 - 144. 